
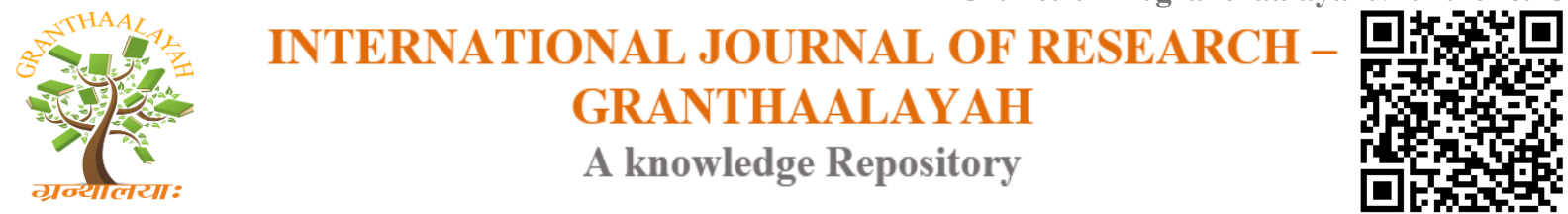

Science

\title{
ASSESSMENT OF NURSES KNOWLEDGE AND PRACTICE REGARDING CARE OF ASTHMATIC CHILD IN ELMAK NIMER HOSPITAL
}

\author{
Dr. Suleman Elkamil Ahmed ${ }^{1}$, Nashwa Fath Elrhaman Ahmed ${ }^{2}$, Dr. Dawria Adam ${ }^{3}$ \\ ${ }^{1}$ Ph.D, Associate Professor and Dean Faculty of Public Health in Shendi University \\ ${ }^{2}$ Nursing Science Researcher at Shendi University Faculty of Nursing Sciences \\ ${ }^{3}$ Ph.D, Assistant Professor and Head Department of Public Health in Shendi University and \\ WHO Independent Consultant
}

\begin{abstract}
This study is a descriptive, analytic, based, cross-sectional study, it was conducted to assess the nurses knowledge and practice regarding care of asthmatic child in Elmek Nemir Hospital as were included 60 nurses. A pre-tested and pre-coded questionnaire consisting of 11 questions, it involved 60 nurses, their experience in paediatric unit between 1 year to more than 7years; their qualification was varies. The study was show that most of the nurses (51.3\%) not know the definition of asthma and more than halve (55\%) of nurses have knowledge about giving oxygen during asthma attack and (61.6\%) of nurses knows the nutritional care of asthmatic patient; regarding performance of nursing skills of asthma most of nurses (63\%) of nurses not know to perform spirometry procedure, instead of (78\%) of nurses know how to give oxygen to asthmatic patient, the study recommend that administrator should develop Continues education activities for nurses should to increase knowledge and practice of the nurses to be skilful; establish of educational poster in nurses office consist most important interventional activities for asthmatic patient.
\end{abstract}

Keywords:

Asthmatic Child, asthmatic patient, Nurses Knowledge, Public Health.

Cite This Article: Dr. Suleman Elkamil Ahmed, Nashwa Fath Elrhaman Ahmed, and Dr. Dawria Adam, "ASSESSMENT OF NURSES KNOWLEDGE AND PRACTICE REGARDING CARE OF ASTHMATIC CHILD IN ELMAK NIMER HOSPITAL" International Journal of Research - Granthaalayah, Vol. 4, No. 2 (2016): 39-45.

\section{INTRODUCTION}

From before birth through to young adult hood there are arrange of health issues that affect our children. Child health covers many of those issues. From general child hood illnesses, Nutrition and obesity to allergies and parenting advice. In addition is a discussion on many of the controversial issues that parents have to deal with in regards to their children's health (1). 
Respiratory system disease in children is there have upper respiratory tract infection disease like respiratory syncytial virus ( $\mathrm{R} \mathrm{S} \mathrm{V}$ ), common cold, sinusitis, tonsillitis, otitis media, pharangitis and laryngitis. The lower respiratory tract infection is pneumonia usually caused by bacteria or fungi or viruses, respiratory tumors, T. B and asthma (2).

Asthma is a chronic inflammatory disease of the air way resulting in air way hyper responsiveness mucosal edema, and mucus productive. Asthma is a common disease in the world affect more than $15 \%$ all over the world of the population.

Asthma is a common chronic inflammatory condition of the lung air way whose cause is in completely understood, symptoms are cough, wheeze chest tightness and shortness of breath often worse at night. It has three characteristics:

- Air flow limitation which is usually reversible spontaneously or with treatment. In chronic asthma inflammation may lead to irreversible air flow limitation, Air way hyper responsiveness to a wide range of stimuli.

- Inflammation of the bronchi with easinophils, lymphocytes and most cells with associated plasma exudation, Edema, smooth muscle hypertrophy mucus plugging and epithelial changes.

- The under lying pathology in preschool children may be different in they may exhibit appreciable bronchial hyper activity.

There is no evidence that chronic inflammation is the basis for the episodic asthma associated with viral infections (3).

Asthma can occur at any age and is the most common chronic disease of child hood.

The death rate of asthma continuous to increase affecting school and work, attendance, occupational choices, physical activity, and quality of life in general. In many countries the prevalence of asthma is increasing, particularly in the second decade of life where this disease affects (10-15) \% of the population. (4).

In the Sudan the prevalence of asthma in Khartoum children is about $16 \%$. (5).Asthma provokes by many factors including allergy, stress or emotional up sets, dusts, weather change, exertion (6).

In Shendi town may be the cause of asthma are triggering factors. The nurse must be explaining the hazards of upper respiratory tract infections.

(U R I) and suggest that the child avoid contacts with infected persons, and receive immunization. The nurse should also strongly recommend that the child take antibiotics as prescribed if sputum becomes yellow or green and avoiding potential triggers could immunize the chances of the child acquiring and upper respiratory tract infections (U R I).The rational of this study, Asthma is very important and common problem in pediatric patient. While understanding of asthma has increase in recent years. The morbidity and mortality associated with these chronic conditions continue to comprise a major health dilemma. 


\section{METHODOLOGY}

\section{STUDY DESIGN}

The design used for this study was descriptive, cross-sectional facility based it was aiming to assess the nurse's knowledge and practice regarding care of asthmatic child in Elmak Nimer Hospital.

\section{STUDY AREA}

This study was conducted in Elmak Nimer Hospital which located at River Nile state in Shendi town; the hospital was established in 2002 and contains the following departments: medicine, surgery, pediatric, Gynecology and obstetrics unit.

\section{STUDY TIME FRAME}

This study was carried out during the period which extends from September to December 2012.

\section{STUDY POPULATION AND SAMPLE}

The study covered 60 samples composing all nurses who worked and those who are still working in pediatric unit in Elmak Nimer university hospital and there have 100 nurses in the hospital.

\section{DATA COLLECTION TOOLS}

Structured interviewed schedule that was developed by the researcher after a thorough review of literatures to collected data about assessment of nurses knowledge and practice regarding care of asthmatic child in Elmak Nimer Hospital.

\section{ETHICAL CONSIDERATION}

A clarification of the aim of the study to the hospital administrators and matron had been done, in order to take their permission to carry out the study, then a clarification of the aim of the study to each of the nurse had been done, to be familiar with the importance of their participation, in addition, assuring them that, all obtained information should be only used for the research purpose.

\section{DATA ANALYSIS TECHNIQUE}

The data was analyzed by computer using software program SPSS version 17 and presented in forms of tables and figures.

\section{RESULTS}

Table 1: Demographic factors of the study population

\begin{tabular}{|l|l|l|}
\hline Variable & Frequency & Percent \\
\hline sex & 06 & $09.8 \%$ \\
\hline Male & 54 & $90.2 \%$ \\
\hline Female & & \\
\hline Total & 60 & $100 \%$ \\
\hline
\end{tabular}




\begin{tabular}{|c|c|c|}
\hline \multicolumn{3}{|l|}{ Qualification } \\
\hline Diploma & 04 & $06.6 \%$ \\
\hline Graduate & 41 & $68.8 \%$ \\
\hline Post graduate & 15 & $24.6 \%$ \\
\hline Total & 60 & $100 \%$ \\
\hline \multicolumn{3}{|l|}{ years } \\
\hline$>3$ years & 09 & $14.8 \%$ \\
\hline $3-6$ years & 44 & $73.7 \%$ \\
\hline $6-7$ years & 07 & $11.5 \%$ \\
\hline Total & 60 & $100 \%$ \\
\hline
\end{tabular}

Table 2: Nurses knowledge and background regarding Asthma's sign and symptoms

\begin{tabular}{|l|l|l|}
\hline Items & Frequency & Percent \\
\hline Audible wheezing & 35 & $58.3 \%$ \\
\hline Cyanosis & 13 & $21.7 \%$ \\
\hline Prolonged expiratory Phase & 06 & $10 \%$ \\
\hline Frothy productive cough & 06 & $10 \%$ \\
\hline Total & 60 & $100 \%$ \\
\hline
\end{tabular}

Table 3: Nurses knowledge regarding the significant investigations for Asthma patients

\begin{tabular}{|l|l|l|}
\hline Items & Frequency & Percent \\
\hline Blood gases analysis & 42 & $70 \%$ \\
\hline Chest x- ray & 10 & $16.6 \%$ \\
\hline Peak expiratory flow rate & 04 & $6.7 \%$ \\
\hline
\end{tabular}




\begin{tabular}{|l|l|l|}
\hline Pulmonary function test & 04 & $6.7 \%$ \\
\hline Total & 60 & $100 \%$ \\
\hline
\end{tabular}

Table 4: Nurses practicing and knowledge concerning patients positioning

\begin{tabular}{|l|l|c|}
\hline Items & Frequency & Percent \\
\hline Semi sifting position & 45 & $75 \%$ \\
\hline Sitting position & 08 & $13.3 \%$ \\
\hline Supine position & 04 & $06.7 \%$ \\
\hline Lateral position & 03 & $05 \%$ \\
\hline Total & 60 & $100 \%$ \\
\hline
\end{tabular}
Allergic disease
chronic disease
genetic disease
incommunicable disease

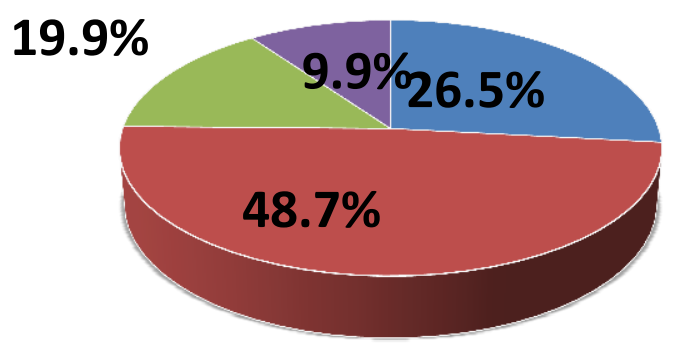

Figure 1: Nurses knowledge about the types of Asthma 


\section{DISCUSSION}

This study is a descriptive analytic based cross-sectional study, conducted to assess the nurses knowledge and practice regarding care of asthmatic child in Elmak Nimer Hospital as were included in 60 nurses this study, in the period extending from October 2012. A pre-tested and pre-coded questionnaire consisting of 11 question, it involved 60 nurses, their experience in pediatric unit between 1 year to more than 7years; their qualifications were varies.

The study revealed most of the study group was female $(90.2 \%)$, most of them were graduated $(68.8 \%),(73.3 \%)$ of them had years of experience between (3-6) years as in table no (1).

Near half of the participants were known what is asthma (48.7\%) that agrees with Praveen Kumar in year 1999 that asthma is chronic disease. Most half of nurses (58.3\%) known the signs of asthma is audible wheezing that agree with Praveen Kumar in year (1999) a ${ }^{(2)}$. In side of quarter of the result $(25 \%)$ of triggers factors is weather and $(23 \%)$ is allergens and exercise that evidence by Jenkins c, lostelloj \&Hodge in year (2004). More than half of the result (55\%) given Oxygen therapy during acute attack of asthma that agree with Charles v. man in year (1995) . More than half of the result (61.7\%) the repeated attack of asthma can cause barrel chest as supported to Charles v. man in year (1995). Less than two third (63.4\%) of nurses aware about delayed complication pneumo thorax that supported with Josef (2008). More than half of nurses (61.6\%) the nutritional care of asthmatic child is I.V infusion as appropriate rate that agree with Praveen Kumar in year (1999). In doing chest physiotherapy there is doing four procedures. The study clarified that more than half of nurses $(60 \%)$ is doing good abdominal or diaphragmatic breathing procedure. In doing deep breathing and coughing exercise less than two third (65\%) of nurses is doing well (10).

In doing pursed lip breathing less than two third (73\%) is doing well ${ }^{(12)}$. But the practice of nurses in doing spirometery more than quarter $(36 \%)$ is doing poor and that because the spirometery is not available in Elmak Nimer hospital and the nurses is not skilful and not trained enough as in table no (11). In administering oxygen by mask more than two third (83\%) is doing good as in table no (13) and then two third (78\%) of nurses during doing ventolin nebulizer is doing good as in table no (14). There the study show that all of this procedure except the spirometery the nurses is doing good because the skillful and the repeated of these procedure.

\section{CONCLUSION}

Based on the finding of the present study, it was concluded that more than half of nurses have a good knowledge about asthma (definition, triggers factor, repeated attack, complication), and more than half of nurses have a good awareness regarding asthmatic child's in hospital and the other half their awareness distribute between fair and poor awareness.

\section{RECOMMENDATION}

Based on the study finding and conclusion, the following recommendations are required to be implemented by the administration of the Elmak Nimer Hospital Continues education programs for nurses should be established to increase knowledge and practice of the nurses to be skillful. 
Additionally, frequent workshops about asthma disease should be developed by professional nurses to improve nurse's quality in paediatric unit. By the head nurses of the paediatric department an application of educational posters in nurse's office consists of signs and symptoms, intervention and management of asthma to increase knowledge and practice of the nurses.

\section{REFERENCES}

[1] WWW.Child health.com /au/ -cached in17/October at 9:23 am

[2] Doctors - hospitals- medicals - cope town in19/October at8:30 Am.

[3] Charles v. man - bailey and loves: second edition, educational low - priced books schema, British, (1995) pages (512 - 520).

[4] Joseph - parrillo - $R$ - Phillip D ellinger - eritical care medicine Third edition, library of congress cataloging, china, (2008), pages (806)

[5] Basher etal - child hood asthma in Gadarif, International Journal of Tuberculosis and lung disease (2003) pages (7 - 11).

[6] Ibrahim - management of child hood asthma in the tropics: Sudan, (1990), Medical Journal, pages (28).

[7] Suzanne C. smettzer Brenda G Bara-Medical surgical Nursing : $\quad 9$ Th edition, lihighpress, inc . U k, (2000), pages (460 -469).

[8] Mohamed etal _ prevalence of asthma and allergen Sudan: (2004) , page (252).

[9] Jenkins C, lostelloj and Hodge $L$ - systemic review of prevalence of Aspirin induced asthma and it is implications for clinical practice: British Medical Journal, (2004) pages (328-434).

[10] Brunner and Siddhartha's - text book of medical surgical nursing, 9th edition, network, lippincoh parvenu, (2000) pages ( 374 - 377 ).

[11] Praveen Kumar Michael Clark _ Kumar: Third edition. British of Congress cataloging and library of congress cataloging, china, (1999) Pages (673 - 667). 